\title{
Gambaran Efikasi Diri Pasien yang Menjalani Hemodialisis
}

\author{
Devia Putri Lenggogeni*, Hema Malini, Rika Fatmadona, Ega Silvia Roza \\ Fakultas Keperawatan, Universitas Andalas \\ *Correspondence email: deviaputri@nrs.unand.ac.id
}

\begin{abstract}
Abstrak. Efikasi diri merupakan persepsi kemampuan individu untuk merencanakan dan melaksanakan suatu tindakan. Efikasi diri diperlukan oleh gagal ginjal terminal yang menjalani hemodialisis untuk dapat melakukan manajemen diri yang baik. Penelitian ini merupakan penelitian dengan menggunakan desain deskriptif. Jumlah sampel yang digunakan pada penelitian ini berjumlah 63 orang. Pengambilan sampel dilakukan dengan teknik consecutive sampling. Pengambilan data menggunakan kuesioner Chronic Kidney Disease Self Efficacy (CKD-SE). Hasil penelitian menunjukkan karakteristik responden memiliki rentang usia terbanyak adalah 41-60 tahun $(66,7 \%)$, jenis kelamin responden terbanyak adalah laki-laki $(60,3 \%)$, pendidikan tertinggi responden adalah SMA (47,6\%), sebagian besar responden yang menjalani hemodialisis masih bekerja (61.9\%), etiologi dari gagal ginjal terminal paling banyak disebabkan oleh penyakit ginjal hipertensi (52.4\%) dan lama menjalani hemodialisis paling banyak adalah < 12 bulan (71.4\%). Rerata skor self-efficacy adalah 72.25. Sub variabel self-efficacy paling tinggi adalah sub-variabel otonomi dengan rerata skor 23.51. Penilaian self-efficacy dengan menggunakan CKD-SE dapat digunakan pada pasien gagal ginjal terminal yang menjalani hemodialisis. Dengan mengetahui self-efficacy dapat memudahkan perawat dalam melakukan edukasi sehingga dapat meningkatkan self-management pasien yang menjalani hemodialisis.
\end{abstract}

Kata Kunci: gagal ginjal terminal; hemodialysis; efikasi diri

Abstract. Self-efficacy is an individual's perception of their ability in carrying out of action. Self-efficacy is required by end-stage renal disease patients undergoing hemodialysis to be able to carry out good self-management. This research was using a descriptive design. The number of samples used in this study amounted to 63 people. Sampling was done by consecutive sampling technique. Data was collected by using Chronic Kidney Disease Self Efficacy (CKD-SE) questionnaire. Based on this study was known that the largest age range is 41-60 years (66,7\%), the most respondent is male (60.3\%), the most respondent is still working (61.9\%), the most etiology of end stage renal disease is hypertensive renal disease (52.4\%), the highest education of respondents is senior high school (47.6\%), duration hemodialysis is < 12 months (71.4\%). The mean score of self-efficacy was 72.25. The highest sub-variable of self-efficacy is autonomy which a mean score 23.51. Self-efficacy assessment using CKD-SE can be used in patients undergoing hemodialysis. Knowing self-efficacy can help a nurse to educate patients, so that will improve self-management patients undergoing hemodialysis.

Keywords: end-stage renal disease; hemodialysis; self-efficacy

\section{PENDAHULUAN}

Gagal Ginjal Terminal (GGT) merupakan penyakit ginjal kronis stadium lima yang ditandai dengan kerusakan ginjal yang bersifat progressif dan irreversible dimana terjadi penurunan laju filtrasi glomerulus < 15ml/menit/1,73 m2. (National Kidney Foundation [NKF], 2015; National Institute of Diabetes and Digestive and Kidney Diseases [NIDDK], 2014). Penurunan fungsi ginjal pada pasien gagal ginjal terminal akan menyebabkan gangguan homeostatis tubuh berupa gangguan pengaturan volume cairan tubuh, gangguan proses eksresi zat sisa hasil metabolisme, gangguan pengaturan keseimbangan asam basa dan elektrolit tubuh yang akan menimbulkan manifestasi klinis dan masalah pada pasien gagal ginjal terminal (Solini \& Ferrannini, 2011).

Pada pasien GGT untuk mempertahankan kelangsungan hidup maka diperlukan terapi pengganti ginjal. Adapun terapi jenis terapi pengganti ginjal antara lain hemodialisis, peritoneal dialisis dan transplantasi ginjal. Diantara ketiga jenis terapi pengganti ginjal tersebut, hemodialisis merupakan jenis terapi pengganti ginjal yang paling banyak digunakan Makhlough, Ilali,
\& Mohseni (2012). Hemodialisis adalah terapi pengganti ginjal yang mampu melakukan ekskresi produk sisa metabolisme dan mempertahankan keseimbangan cairan dan elektrolit melalui selaput membran semipermiabel yang dapat berperan sebagai ginjal buatan (Sukandar, 2013).

Hemodialisis sebagai terapi pengganti ginjal bekerja dengan mengeksresikan atau menghilangkan kelebihan cairan dan produk sisa metabolisme tubuh. Secara klinis hemodialisis dapat memperpanjang waktu survival dan meningkatkan kualitas hidup pasien GGT. Meskipun demikian, keberhasilan proses hemodialisis sangat ditentukan oleh kepatuhan dalam menjalani serangkaian manajemen pasien GGT yang menjalani hemodialisis (Wang et al., 2018).

Efikasi diri diperlukan pada pasien GGT yang menjalani hemodialisis untuk dapat melakukan managemen diri yang baik. Berdasarkan beberapa hasil penelitian efikasi diri berpengaruh besar terhadap manajemen diri yang efektif sehingga dapat meningkatkan hasil dan mencegah memburuknya penyakit (Curtin et al., 2008). Efikasi diri merupakan salah satu bentuk kepercayaan individu pada dirinya 
sendiri dalam melakukan suatu tindakan (Bandura, 1997). Adanya keyakinan tersebut akan mempengaruhi manajemen diri pasien yang menjalani hemodialisis seperti melakukan aktivitas sehari-hari dan kepatuhan terhadap pengobatan ( $\mathrm{Li}$ et al., 2014). Efikasi diri dapat memprediksi kepatuhan dalam regimen pengobatan, perilaku kesehatan dan aktivitas fisik, manajemen nyeri yang efektif serta manajemen penyakit (Luszczynska et al., 2005)

Efikasi diri memiliki efek positif dalam keterlibatan perilaku yang mempromosikan kesehatan, motivasi, gaya berpikir dan kesehatan emosional dan mengatasi batasan hidup. Efikasi diri yang tinggi dihubungkan dengan manajemen yang baik (Mahmoud \& AbdElaziz, 2015).

Penelitian yang dilakukan oleh Li et al., (2014) juga menunjukkan bahwa efikasi diri mempunyai korelasi positif dengan manajemen diri pada pasien yang menjalani hemodialisis. Hasil penelitian menunjukkan bahwa efikasi diri yang rendah dikaitkan dengan ketidakpatuhan pasien yang menjalani hemodialisis dalam menjalani pengobatan. Dengan kata lain seseorang dengan efikasi diri yang tinggi akan memiliki manajemen diri yang baik begitu pula sebaliknya.

Efikasi diri merupakan kunci untuk mencapai sesuatu dari apa yang dipikirkan, dipercayai, dirasakan dan diharapkan (Bandura, 1997). Efikasi diri dibutuhkan oleh pasien GGT yang menjalani hemodialisis untuk dapat mengelola penyakitnya. Oleh karena itu penting untuk mengetahui gambaran efikasi diri pada pasien GGT yang menjalani hemodialisis.

\section{METODE}

Penelitian ini merupakan penelitian dengan desain deskriptif analitik menggunakan pendekatan cross sectional. Populasi pada penelitian ini pasien yang menjalani hemodialisis rutin. Jumlah sampel pada penelitian ini adalah 63 orang pasien. Teknik pengambilan sampel dilakukan dengan teknik consecutive sampling. Kriteria inklusi yakni pasien hemodialisis yang berusia 18 tahun atau lebih, pasien yang rutin menjalani hemodialisis dua kali dalam seminggu, riwayat menjalani hemodialisis minimal 3 bulan terakhir. Pengambilan data dilakukan dengan kuesioner Chronic Kidney Disease Self Efficacy Instrument (CKD-SE). Uji instrument dilakukan pada 30 pasien yang menjalani hemodialisis. Hasil uji kuesioner CKD-SE didapatkan nilai validitas $0,59-0,91$ dan nilai reliabilitas 0,845

\section{HASIL DAN PEMBAHASAN}

Tabel 1. Distribusi Frekuensi Karakteristik Responden di Unit Hemodialisa RSUP DR.M.Djamil Padang $(\mathrm{n}=63)$

\begin{tabular}{lcc}
\hline \multicolumn{1}{c}{ Karakteristik Responden } & f & \% \\
\hline Usia & & \\
Dewasa awal (18-40 tahun) & 10 & 15.9 \\
Dewasa madya (41-60 tahun) & 42 & 66.7 \\
Dewasa lanjut (> 60 tahun) & 11 & 17.5 \\
\hline Jenis Kelamin & & \\
Laki-laki & 38 & 60.3 \\
Perempuan & 25 & 39.7 \\
\hline Pendidikan Terakhir & & \\
SD & 3 & 4.8 \\
SMP & 10 & 15.9 \\
SMA & 30 & 47.6 \\
Perguruan Tinggi & 20 & 31.7 \\
\hline Pekerjaan & & \\
Bekerja & 39 & 61.9 \\
Tidak Bekerja & 24 & 38.1 \\
\hline Diagnosis Etiologi & & \\
Penyakit Ginjal HIpertensi & 33 & 52.4 \\
Nefropati Diabetika & 16 & 25.4 \\
Ginjal Polikistik & 1 & 1.6 \\
Nefropati Asam Urat & 4 & 6.3 \\
Nefropati Obstruksi & 5 & 7.9 \\
Lain-lain & 4 & 6.3 \\
\hline Lama HD & & \\
< 12 bulan & 45 & 71.4 \\
$\geq 12$ bulan & 63 & 28.6 \\
\hline Total & & 100 \\
\hline
\end{tabular}

Berdasarkan karakteristik responden dari segi usia diketahui diketahui bahwa lebih dari setengah $(66,7 \%)$ pasien gagal ginjal kronik yang menjalani hemodialisis berusia dewasa madya (41-60 tahun), lebih dari sebagian besar pasien yang menjalani hemodialisis berjenis kelamin laki-laki $(60,3 \%)$, kurang dari setengah pasien yang menjalani hemodialisis mempunyai pendidikan terakhir SMA (47,6\%), sebagian besar responden yang menjalani hemodiaisis masih bekerja (61.9\%), etiologi dari gagal ginjal terminal paling banyak disebabkan oleh penyakit ginjal hipertensi $(52.4 \%)$ dan lebih dari sebagian besar responden $(71,4 \%)$ telah menjalani hemodialisis kurang dari 12 bulan.

Tabel 2. Nilai Rerata dan Standar Deviasi Efikasi Diri Pasien GGK yang Menjalani Hemodialisis di RSUP DR. M. Djamil Padang $(\mathrm{n}=63)$

\begin{tabular}{ccccc}
\hline $\mathrm{n}$ & Mean & Std. Deviasi & Min & Max \\
\hline 63 & 72.25 & 9.73 & 48 & 91 \\
\hline
\end{tabular}

Berdasarkan hasil penelitian diketahui rerata skor efikasi diri adalah 72,25 dengan standar deviasi 9,729. Nilai skor efikasi diri terendah adalah 48 dan skor tertinggi adalah 91. Selain itu, sesuai dengan kuesioner yang digunakan, rerata 72,25 menunjukkan bahwa efikasi diri pasien gagal ginjal kronik yang menjalani hemodialisis berada pada efikasi diri sedang. Efikasi diri sedang yang dimiliki responden dapat dilihat dari jawaban responden pada kuesioner dimana lebih dari 
setengah responden $(71,4 \%)$ cukup aktif mendiskusikan rencana perawatan dengan keluarga atau teman untuk mendapatkan dukungan, selain itu lebih dari setengah responden $(69,8 \%)$ menyatakan dapat menemukan sumber daya yang dibutuhkan dalam mengendalikan penyakit gagal ginjalnya.

Penelitian yang dilakukan oleh Panjaitan et.al (2015) menjelaskan keluarga sangat penting untuk setiap aspek perawatan mulai dari tahap perencanaan hingga fase rehabilitasi. Adanya dukungan dari keluarga membuat pasien mendapatkan informasi, melakukan monitoring dan melakukan adaptasi dengan penyakitnya.

Pada hasil penelitian ini masih terdapat sebagian kecil responden $(3,2 \%)$ memiliki efikasi diri yang rendah. Hal ini menunjukkan bahwa pasien memiliki ketidakyakinan akan kemampuan yang dimiliki, adanya penurunan rasa percaya diri dan ragu-ragu dalam menentukan tindakan yang akan dilakukan untuk mencapai tujuan, termasuk dalam melakukan manajemen diri. Penelitian yang dilakukan oleh Purba et al. (2018) menunjukkan efikasi diri yang rendah dapat disebabkan karena hilangnya kepercayaan diri dalam hidupnya terkait kondisi saat ini.

Efikasi diri akan mempengaruhi kemampuan perawatan diri, kepatuhan terhadap pengobatan, dan promosi kesehatan fisik dan mental (Bandura, 1997). Efikasi diri menjadi indikator penting untuk mengevaluasi manajemen diri (Du \& Yuan, 2010). Peningkatan efikasi diri dikaitkan dengan perubahan positif pada manajemen diri. Peningkatan manajemen diri akan memiliki manfaat jangka Panjang bagi pasien GGT yang menjalani hemodialisis (Curtin et al., 2008).

Tabel 3. Nilai Rerata dan Standar Deviasi Sub-Variabel Efikasi Diri Pasien yang Menjalani Hemodialisis di RSUP. DR. M. Djamil Padang $(n=63)$

\begin{tabular}{llllll}
\hline Sub-Variabel Self Efficacy & $\mathrm{n}$ & Mean & Std. Deviasi & Min & Max \\
\hline Otonomi & 63 & 23.51 & 3.49 & 15 & 30 \\
Integrasi Diri & 63 & 18.65 & 4.24 & 7 & 27 \\
Penyelesaian Masalah & 63 & 17.76 & 3.34 & 10 & 24 \\
Mencari Dukungan Sosial & 63 & 12.33 & 1.91 & 6 & 15 \\
\hline
\end{tabular}

Hasil penelitian menunjukkan sub-variabel efikasi yang paling tinggi adalah otonomi yaitu 23,51 dengan standar deviasi 3,487. Hasil analisis kuesioner diketahui lebih dari setengah responden $(69,8 \%)$ mengatakan merasa nyaman memberi tahu orang lain bahwa ia menderita gagal ginjal, selain itu lebih dari setengah responden $(63,5 \%)$ mengatakan merasa nyaman untuk menghubungi dokter dan berbicara tentang pengobatan gagal ginjalnya.

Hasil penelitian ini sejalan dengan penelitian Mahmoud (2015), dimana pada penelitian tersebut subvariabel efikasi yang paling tinggi adalah otonomi. Hal ini mungkin disebabkan karena pasien mengidentifikasi bahwa hemodialisis dapat memperpanjang usia mereka tetapi dapat menurunkan kualitas hidup yang signifikan. Pasien juga harus terlibat dalam mengatasi keterbatasn akibat hemodialisis bahwasanya dimana pada penelitian tersebut diketahui bahwa pasien hemodialisis memiliki otonomi yang tinggi untuk mengatasi pembatasan akibat dialisis. Hal inilah yang membuat pasien bertanya dan berdiskusi dengan dokter dan petugas kesehatan tentang penyakit dan apa yang harus mereka lakukan. Pasien mungkin juga mengalami perubahan dalam kehidupan sehari-hari mereka, tidak bisa melakukan kegiatan seperti biasa, memiliki ketidakpastian tentang masa depan dan khawatir terhadap pekerjaaan dan pernikahan sehingga pasien tertarik untuk mengetahui segala hal tentan hemodialisis untuk mengatasi komplikasi dan mengurangi beban perawatan keluarga.

\section{SIMPULAN}

Hasil penelitian menunjukkan karakteristik responden dalam penelitian ini memiliki rentang usia terbanyak adalah 41-60 tahun $(66,7 \%)$, jenis kelamin responden terbanyak adalah laki-laki $(60,3 \%)$, pendidikan tertinggi responden adalah SMA $(47,6 \%)$, sebagian besar responden yang menjalani hemodialisis masih bekerja (61.9\%), etiologi dari gagal ginjal terminal paling banyak disebabkan oleh penyakit ginjal hipertensi (52.4\%) dan lama menjalani hemodialisis paling banyak adalah $<12$ bulan $(71.4 \%)$. Rerata skor self-efficacy adalah 72.25. Sub variabel self-efficacy paling tinggi adalah sub-variabel otonomi dengan rerata skor 23.51. Penilaian self-efficacy dengan menggunakan CKD-SE dapat digunakan pada pasien gagal ginjal terminal yang menjalani hemodialisis. Dengan mengetahui efikasi diri dapat memudahkan perawat dalam melakukan edukasi sehingga dapat meningkatkan manajemen diri pasien yang menjalani hemodialisis.

\section{DAFTAR PUSTAKA}

Bandura, A. (1997). Self Efficacy - The Exercise of Control (Fifth Printing, 2002). New York: W.H Freeman \& Company.

Curtin, R. B., Walters, B. A. ., Schatel, D., Pennel, P., Wise, M., \& Kristi, K. (2008). Self-Efficacy and Self-Management Behaviors in Patients With Chronic Kidney Disease. Advances in Chronic Kidney, 15(2), 191-205. https://doi.org/10.1053/j.ackd.2008.01.006

Du, S., \& Yuan, C. (2010). Evaluation of patient selfmanagement outcomes in health care: a systematic 
review. Int Nurs Rev, 57(2), 159-167. https://doi.org/https://doi.org/10.1111/j.14667657.2009.00794.X

Li, H., Jiang, Y. fang, \& Lin, C. C. (2014). Factors associated with self-management by people undergoing hemodialysis: A descriptive study. International Journal of Nursing Studies, 51(2), 208-216.

https://doi.org/10.1016/j.ijnurstu.2013.05.012

Luszczynska, A., Gutiérrez-Doña, B., \& Schwarzer, R. (2005). General self-efficacy in various domains of human functioning: Evidence from five countries. International Journal of Psychology, 40(2), https://doi.org/10.1080/00207590444000041

Mahmoud, S., \& AbdElaziz, N. A. (2015). Association between Health Locus of Control, Self-care and Self-efficacy in Patients with End Stage Renal Disease Undergoing Hemodialysis. Life Science Journal, 12(11), 58-72. https://doi.org/10.1145/3132847.3132886

Makhlough, A., Ilali, E., \& Mohseni, R. (2012). Effect of Intradialytic Aerobic Exercise on Serum Electrolytes Levels in Hemodialysis Patients. Iranian Journal of Kidney Disease, 6(2), 119-123.

National Institute of Diabetes and Digestive Kidney Disease. (2014). Kidney Disease Statistics for The United States. Retrieved from https://www.niddk.nih.go

National Kidney Foundation. (2015). KDOQI. Clinical Practice Guidelines and Clinical Practice Recommendation. Retrieved from https://www.kidney.org

Panjaitan, E.M., Siregar, M.A., \& Sudaryati, E. (2015). Gambaran kepatuhan diet dan dukungan keluarga pada penderita gagal ginjal kronik yang menjalani hemodialisa di Rawat Jalan RSU Haji Medan Tahun 2014. Jurnal Universitas Sumatera Utara, $1(2)$

Purba, A. K., Emaliyawati, E., \& Sriati, A. (2018). SelfManagement and Self-Efficacy In Hemodialysis Patients. Journal of Nursing Care, 1(2), 129-139. https://doi.org/10.24198/jnc.v1i2.16137

Solini, A., \& Ferrannini, E. (2011). Pathophysiology , Prevention and Management of Chronic Kidney Disease in the Hypertensive Patient With Diabetes Mellitus. The Journal of Clinical Hypertension, 13(4), 252-257. https://doi.org/10.1111/j.17517176.2011.00446.x

Sukandar, E. (2013). Nefrologi Klinik. Pusat Informasi Ilmiah (PII) Departemen Ilmu Penyakit Dalam Fakultas Kedokteran Universitas Indonesia.

Wang, J., Yue, P., Huang, J., Xie, X., Ling, Y., Jia, L., Xiong, Y., \& Sun, F. (2018). Nursing Intervention on the Compliance of Hemodialysis Patients with End-Stage Renal Disease: A Meta-Analysis.
Blood Purification, 45, 102-109. https://doi.org/10.1159/000484924 